\title{
MARKETINGOVÁ KOMUNIKÁCIA - VÝZNAMNÝ NÁSTROJ MARKETINGOVÉHO INŠTRUMENTÁRIA ŠTÁTNEJ VYSOKEJ ŠKOLY
}

\author{
Viera Frianová*
}

\section{Úvod}

Napriek tomu, že v inštitúciách a organizáciách verejného a neziskového sektora na Slovensku nepatrí marketing medzi tradičné činnosti, naopak je riadiacimi pracovníkmi organizácií často odmietaný, každodenná prax potvrdzuje skutočnost', že v stále silnejúcom konkurenčnom prostredí sa jeho uplatňovanie aj v tomto sektore javí ako nevyhnutnost'.

Ked’že súčasná forma marketingu reprezentuje najmodernejší spôsob riadenia, podnikatel'ského myslenia a konania v konkurenčnom prostredí, možno marketing, napriek odmietavým postojom niektorých riadiacich pracovníkov, považovat' za najvhodnejšiu koncepciu riadenia aj pre všetky typy vysokých škôl (vrátane štátnych), ktoré v trhovom prostredí predstavujú ,ppodniky“ poskytujúce vzdelanie [1].

Dôležitou a neoddelitel'nou súčast’ou marketingového riadenia každej vysokej školy je marketingové inštrumentárium označované aj ako marketingový mix. Osobitosti Akadémie ozbrojených síl gen. M. R. Štefánika v Liptovskom Mikuláši ako jediného subjektu na Slovensku poskytujúceho služby v špecifickej oblasti vysokoškolského vzdelávania v sústave študijných odborov obrana a vojenstvo sa premietajú aj do potreby využívania špecifických marketingových nástrojov, medzi ktoré nesporne patrí aj marketingová komunikácia.

\section{Postavenie a význam štátnej vojenskej vysokej školy na trhu vzdelávania}

Z pohl'adu podnikovohospodárskej náuky, ktorá ponúka kritériá pre členenie subjektov národného hospodárstva SR, možno Akadémiu ozbrojených síl gen. $\mathrm{M}$. R. Štefánika so sídlom v Liptovskom Mikuláši považovat' za subjekt neziskový - je to rozpočtová organizácia [2] financovaná prostredníctvom rozpočtovej kapitoly Ministerstva obrany SR; subjekt verejný - je to verejno-právna inštitúcia, ktorej poslaním je rozvíjat' harmonickú osobnost', vedomosti, zručnosti a tvorivost' študujúcich a prispievat' k rozvoju vzdelanosti, vedy, techniky a kultúry v oblastiach dôležitých pre obranu Slovenskej republiky. V súlade s poslaním a zákonmi SR akadémia rozvíja predovšetkým pedagogickú, vedeckú, výskumnú a vývojovú činnost' [3]. V ekonomickom zmysle teda reprezentuje verejný štátny podnik poskytujúci služby v oblasti vzdelávania/vzdelávacie služby, pričom pri plnení jeho úloh prebiehajú v spojení s didaktickými, vedeckými, právnymi a d’alšími procesmi tiež mnohé hospodárske procesy, pri ktorých dochádza k spotrebe vstupných statkov. Na druhej

\footnotetext{
* Ing. Viera Frianová, Katedra manažmentu, Akadémia ozbrojených síl gen. M. R. Štefánika, Liptovský Mikuláš tel.: +4210950 423525

e-mail: viera.frianova@aos.sk
} 
strane je potrebné zdôraznit', že sa od tradične ponímaných podnikov škola odlišuje predovšetkým:

- druhom realizovaných výkonov (vzdelávacie služby sa vyznačujú najmä bezplatnost'ou výkonov voči študentom, dominanciou l'udského faktora, dominanciou nehmotného charakteru, vysokou spoluúčast'ou zákazníka/študenta pri produkcii, zredukovanou úlohou sprostredkovatel'ov pri poskytovaní, dôležitost'ou vzájomného kontaktu medzi poskytovatel'om a zákazníkom, pominutel'nost'ou, potrebou dospiet' k zosúladeniu stále rastúceho dopytu/záujmu o štúdium na danej škole a ponuky atd'.);

- ciel'mi voblasti odborného vojenského výcviku, vyučovacími a výskumnými ciel'mi a úlohami odôvodnenými a určenými vedou, ktoré sa často vymykajú podnikovohospodárskym prístupom a hodnoteniu;

- vnútornou štruktúrou, ktorá je podmienená predovšetkým štruktúrou odborných disciplín (katedry, ústavy, centrá) ako aj potrebou organizovat' a prakticky realizovat' vojenský program kadetov (školské jednotky);

- spôsobom financovania, najmä druhom a rozsahom štátom poskytovaných finančných prostriedkov;

- mnohými špecifickými endogénnymi a exogénnymi faktormi, ktoré ovplyvňujú existenciu a činnost' školy;

- povahou vonkajších vzt’ahov, najmä formou výmenných vzt’ahov medzi školou a jej zákazníkmi.

Ciel'ový trh, ktorý sa škola pokúša svojím produktom ${ }^{1}$ oslovit', teda zákazníkov školy možno rozdelit' do viacerých skupín. Za zákazníkov školy možno považovat' predovšetkým študentov, či už potenciálnych, súčasných, bývalých alebo budúcich. Z iného pohl'adu by sme za zákazníkov školy mohli považovat' rôzne subjekty z hospodárskej praxe (domáce aj zahraničné), s ktorými škola rozvíja spoluprácu predovšetkým v oblasti vzdelávania, výcviku, vedy a výskumu (napr. vnútorné organizačné útvary ozbrojených síl - či už SR alebo d'alších členských štátov NATO, partnerské vysoké školy, špecializované organizácie a inštitúcie, podnikatel'ské subjekty a i.). Ak za „výstup“ školy považujeme odborne erudovaného a vycvičeného profesionálneho vojaka pripraveného na plnenie úloh Ozbrojených síl SR, potom za zákazníkov, ktorí sú nositel'mi určitej spoločenskej objednávky možno považovat' Ministerstvo obrany Slovenskej republiky a Generálny štáb.

\section{Podstata a význam marketingovej komunikácie štátnej vysokej školy}

Marketingová komunikácia je vo všeobecnosti považovaná za dôležitý nástroj pri vytváraní a rozširovaní trhového podielu a pri budovaní imidžu produktu, značky alebo podniku. Vd’aka rastúcej konkurencii na trhu možno práve tento nástroj z hladiska sledovania jednotlivých marketingových stratégií označit' za najdôležitejší [4]. Marketingová komunikácia je v súčasnosti odborníkmi stále častejšie považovaná aj za jednu z najvýznamnejších zložiek marketingového inštrumentária vysokej školy. Prostredníctvom marketingovej komunikácie vysoká škola informuje verejnost' a svojich potenciálnych zákazníkov o svojich ciel'och, aktivitách a ponukách, vzbudzuje v nich záujem o svoje služby.

Proces marketingovej komunikácie každej vysokej školy je zvyčajne zameraný na dosahovanie viacerých ciel'ov, ako sú [1]:

\footnotetext{
${ }^{1}$ Poznámka: produkt - vzdelávací program školy v sebe zahŕňa viaceré súčasti, ako sú: ciel’ové a obsahové zameranie produktu (jednotlivých predmetov), vzdelávacia forma (organizačný rámec vyučovania), dížka vzdelávania, odborná a metodická úroveň vyučovania a doplnkové služby (poskytovanie študijných materiálov a pod.) Je potrebné zdôraznit', že súčast'ou komplexného produktu školy je určite aj výchova, vojenský výcvik, výskum a vývoj.
} 
1. poskytovanie informácií o ponuke/produkte školy (vzdelávacích programoch),

2. vytvorenie alebo vylepšenie imidžu školy,

3. budovanie lojality a podpory absolventov školy,

4. získanie potenciálnych sponzorov,

5. upútanie pozornosti potenciálnych študentov a zvýšenie počtu kvalitných uchádzačov o štúdium,

6. upresňovanie nepresných alebo nekompletných informácií o škole,

7. zist'ovanie a uspokojovanie informačných potrieb internej verejnosti vysokej školy (súčasných študentov, zamestnancov),

8. budovanie vyššej atraktivity vysokej školy v porovnaní s konkurenčnými vysokými školami (doma aj v zahraničí) a s hospodárskou praxou pri prit’ahovaní najkvalitnejších odborníkov (vedecko-pedagogických pracovníkov) na danom trhu práce.

Východiskovým predpokladom úspešnosti procesu marketingovej komunikácie vysokej školy je systematické a dlhodobé budovanie a udržiavanie efektívnej komunikácie s jej ciel’ovými trhmi a publikami. ${ }^{2}$ Za najvýznamnejšie publiká alebo tretie osoby Akadémie ozbrojených síl možno považovat': súčasných a potenciálnych študentov, absolventov školy, rodičov študentov, učitel'ov a vedeckých pracovníkov, administratívnych úradníkov a zabezpečovací personál školy, subjekty hospodárskej sféry, stredné školy, sponzorov, miestnu samosprávu, akreditačné komisie. Osobitnú kategóriu v rámci publík akadémie predstavujú konkurenčné inštitúcie - najmä civilné vysoké školy, ale tiež vojenské vysoké školy v zahraničí, najmä Univerzita obrany v Brne, ktorú možno považovat' jednak do určitej miery za priameho konkurenta akadémie jednak za jej najvýznamnejšieho strategického zahraničného partnera. Azda najvýznamnejšie postavenie medzi ciel'ovými publikami školy má Ministerstvo obrany SR, ktoré plní funkciu zriad'ovatel'a školy, d’alej okrem iného predkladá ministerstvu školstva návrhy na zmeny sústavy študijných odborov obrany a vojenstva, vyjadruje sa k žiadostiam a podkladom školy predkladaným akreditačnej komisii, určuje počty prijímaných študentov, teda vymedzuje svoje požiadavky predovšetkým čo sa týka kvantity absolventov. Ďalším významným publikom je Generálny štáb, ktorý stanovuje požiadavky na profil absolventov Akadémie ozbrojených síl, teda požiadavky determinujúce kvalitu absolventov. Netreba opomenút' ani d’alšie dôležité publiká, ktorými sú: Ministerstvo školstva SR, masmediálne prostriedky a všeobecná verejnost'.

Úlohou marketingovej komunikácie školy je v prvom rade zabezpečit', aby každá ciel'ová skupina/trh vedela, že daná škola existuje a poskytuje v porovnaní $\mathrm{s}$ inými vzdelávacími inštitúciami na trhu určité špecifické služby. Na tomto základe sa následne odvíjajú d’alšie aktivity potenciálnych zákazníkov, ktoré je nutné stimulovat' a pobádat' k reálnemu záujmu a dopytu po poskytovaných službách školy.

\section{Systém integrovanej marketingovej komunikácie štátnej vysokej školy}

Integrovaná marketingová komunikácia (IMC) predstavuje koncept, ktorý oceňuje pridanú hodnotu zrozumitel'ného plánu zohl'adňujúceho strategické role rôznych komunikačných nástrojov (napr. PR, reklamy, podpory predaja a i.), ktoré boli v tradičnom ponímaní na sebe nezávislé. IMC kombinuje tieto nástroje, utvára $\mathrm{z}$ nich ucelený komunikačný mix tak, aby bola dosiahnutá jasnost', konzistencia a maximálny komunikačný dopad [3]. Tvorbu komunikačného mixu každého podniku služieb (nevynímajúc podniky poskytujúce vzdelávacie služby) a zastúpenie jednotlivých prvkov v ňom ovplyvňujú najmä nasledovné skutočnosti: či ide o služby v ziskovom alebo neziskovom sektore, či existujú

\footnotetext{
2 Poznámka: Konkrétne publikum sa stáva trhom vtedy, ked'sa inštitúcia rozhodne, že chce získat' isté zdroje (a to nielen finančné) od tohto publika, pričom výmenou za ne mu ponúka určité hodnoty.
} 
obmedzenia v niektorých profesiách, či je intenzita konkurencie vysoká alebo nízka, či je geografický dosah vel'ký alebo malý, či zvyky v niektorom sektore služieb predurčujú metódy promotion, či je úroveň znalostí a skúseností manažérov vysoká alebo nízka [1].

Podl'a odborníkov pre oblast' vysokoškolských vzdelávacích služieb je možné vo väčšine nástrojov komunikačného mixu aplikovat' nasledovné pravidlá inzercie služieb [5]:

1. Poskytnút' hmatatel'né dôkazy - zaradit' hmatatel'né prvky do okolia základného produktu.

2. Vysvetlit' službu tak, aby bola pochopená - opät' využit' hmotné atribúty služby.

3. Kontinuita komunikácie.

4. Sl'úbit' len to, čo je možné splnit'.

5. Podporovat' ústne podanie - v propagácii služieb je najúčinnejším osobné odporúčanie.

6. Priama komunikácia so zamestnancami - kvôli častému osobnému kontaktu zákazníkov so zamestnancami je nutné komunikáciou zvýšit' zamestnaneckú motiváciu.

Následne možno konštatovat', že systém integrovanej marketingovej komunikácie Akadémie ozbrojených síl sa usiluje určitým spôsobom pri akceptovaní vyššie uvedených pravidiel dosiahnut' želatel'nú zmenu správania sa vybranej ciel'ovej skupiny/publika. Samozrejme úspech tohto úsilia je výrazne determinovaný mierou pochopenia a akceptovania skutočností uvedených jednak v prvej kapitole daného príspevku a tiež v úvodnej časti danej kapitoly.

Za najvýznamnejší a najvhodnejší nástroj marketingovej komunikácie školy možno považovat' aktivity $\mathbf{P R}$, t. j. vzt'ahy s verejnost'ou (jednotlivými publikami školy) či už odbornou alebo laickou - bežnými občanmi, ktoré možno najvýstižnejšie charakterizovat' vetou „pracuj dobre a rozprávaj o tom“. Pomocou PR aktivít sa škola usiluje budovat' pozitívny imidž, resp. tlmit' negatívny imidž. Ide tu teda o komunikačné pôsobenie školy na verejnosti, ktoré vytvára a udržuje pozitívne postoje a vzt'ahy verejnosti k škole, jej aktivitám, službám, študentom atd'. Z realizovaných aktivít Akadémie ozbrojených síl v danej oblasti možno spomenút': organizovanie tlačových konferencií, vedeckých a odborných konferencií a seminárov, brífingov, recepcií, charitatívnych akcií (spolupráca s detskými domovmi, charitatívne zbierky). Súčast’ou PR je aj príprava písomných podkladov, vydávanie interných periodík (časopis Akademik, vedecko-odborný časopis Science \& Military), výstupy publikačnej činnosti (učebnice, skriptá, pracovné manuály), ročné správy, brožúry atd'. Aj ked' vysoká škola v rámci svojej komunikačnej politiky vytvára vzt’ahy s vel'kým množstvom publík, mala by sa zaoberat záujmami a potrebami všetkých týchto publík, najmä však komunikáciou s médiami, ktoré majú v súčasnosti vel'ký vplyv na vytváranie verejnej mienky, a teda aj tvorbu a udržiavanie dobrých vzt’ahov medzi vysokou školou a jej publikami. $\mathrm{Z}$ tohto dôvodu v rámci marketingovej komunikácie akadémie neustále narastá význam tzv. media relations (vzt’ahov s médiami), ktoré zahŕňajú: publikovanie PR článkov v tlači, poskytovanie rozhovorov manažmentu školy médiám, resp. vystúpenia v médiách, realizáciu spoločenských podujatí, ktoré priaznivo pôsobia na budovanie imidžu školy (aktivity event marketingu: dni otvorených dverí, športový deň rektora, týždeň vedy, sút’až ŠVOČ, ples rektora AOS, slávnostné vyradenie absolventov, slávnostné udel'ovanie rezortných vyznamenaní a čestných titulov, ...), lobizmus (najmä ovplyvňovanie zástupcov mesta, VúC, ministerstva obrany na presadzovanie záujmov školy legálnym spôsobom), krízovú komunikáciu (komunikáciu školy v čase krízy - pri objavení sa takých javov ako je napr. šikanovanie, korupcia,...), podnikovú identitu (budovanie vlastnej identity školy).

Každá vysoká škola (akadémiu nevynímajúc) v snahe skvalitnit' a zefektívnit' proces marketingovej komunikácie so svojimi ciel’ovými publikami by mala pri jeho príprave a realizácii zohl'adnit' aj skúsenosti z podnikovej praxe. Tie na jednej strane dokazujú, že ani 
tie najlepšie aktivity PR nezvládnu komunikáciu so silne negatívne naladenou verejnost'ou, predaj nekvalitných služieb, nahradzovanie dobrých činov, zlepšovanie imidžu zlého podniku a pod. $\mathrm{Na}$ druhej strane naopak zdôrazňujú význam PR aktivít v krízovej situácii, v ktorej sa každý podnik, teda aj škola, môže vel'mi l'ahko ocitnút'.

Napriek skutočnosti, že produkt (vzdelávacie služby) sa k zákazníkovi (študentovi) nedostáva prostredníctvom tradične ponímaného predaja, d’alším $\mathrm{z}$ využívaných nástrojov komunikácie Akadémie ozbrojených síl je podpora predaja. V rámci podpory predaja škola využíva možnosti prezentácie školy a jej aktivít v regionálnej Televízii Liptov, na výstavách (IDEB), prehliadkach, na svojej webovej stránke (www.aos.sk), v publicistických reláciách venovaných problematike profesionálnej armády (Profesionál), študenti reprezentujú školu na rôznych športových sút'ažiach, škola spolupracuje s vojenskými útvarmi, s ôsmimi regrutačnými strediskami rozmiestnenými v rámci celého Slovenska, so športovými klubmi mesta atd'. Vydáva tiež propagačné materiály (audiovizuálne materiály: filmy, $\mathrm{CD}$, video, príspevky v časopisoch a odbornej tlači, .....).

V rámci priameho marketingu škola využíva interaktívne médiá, internet, e-mail, spomínanú vlastnú webovú stránku a pod.

Ďalším z nástrojov marketingovej komunikácie školy je osobný predaj, ktorý zahŕňa najmä osobné stretnutia zástupcov školy so zákazníkmi (najmä so súčasnými a potenciálnymi študentmi, so zadávatel'om spoločenskej objednávky) s ciel'om vytvárat' a udržiavat' osobné vzt'ahy, ktoré môžu byt' nielen profesionálne, ale aj priatel'ské (budovanie partnerského vzt'ahu medzi študentmi a učitel'mi).

Vysoká škola môže využívat' aj d'alší z nástrojov komunikácie - reklamu, aj ked' ju v podmienkach školy nemožno uplatnit' $\mathrm{v}$ jej tradičnom ponímaní, predsa len ponúka možnosti využitia či už $v$ televízii, rozhlase, regionálnych novinách, no najmä $v$ propagačných materiáloch školy. Reklama sa v podmienkach vysokej školy využíva na tvorbu imidžu školy, môže však mat' aj podobu informácií napr. o študijných programoch školy, termíne konania prijímacích skúšok, otvorení kurzu a pod. Za hlavné ciele reklamy vysokej školy možno považovat' [1]:

- zvýšenie atraktivity vysokej školy predovšetkým pre tieto publiká: kvalitní uchádzači o štúdium, reálni študenti, najkvalitnejší vedeckí a pedagogickí pracovníci na danom trhu práce, významní nositelia verejnej mienky;

- zvýšenie dopytu po službách vysokej školy;

- tvorba pozitívneho, silného imidžu školy;

- posilnenie finančnej pozície školy;

- motivácia pracovníkov školy.

Je potrebné zdôraznit', že v oblasti vzdelávacích služieb iba samotná reklama zákazníkovi nestačí. Služba musí splnit' očakávania zákazníka, ktoré v ňom reklama vyvolá. Iba tak bude zaručený úspech reklamnej kampane služby a tiež splnenie ciel'ov jej poskytovatel'a.

\section{Záver}

Uvedomujúc si potrebu aplikácie marketingu do vnútorných štruktúr a samotného riadenia Akadémie ozbrojených síl, nové vedenie školy si dalo za ciel' vypracovat' koncepciu precízne formulovaných programov v oblasti marketingu - s dôrazom na marketingovú komunikáciu, ktorej t’ažisko by sa presunulo $\mathrm{z}$ doposial' $\mathrm{v}$ mnohých prípadoch len náhodne či sporadicky realizovaných marketingových akcií a aktivít $\mathrm{k}$ ich premyslenému systematickému plánovaniu a uskutočňovaniu. 


\section{Literatúra}

[1] ŠTEFKO, R.: Akademické marketingové inštrumentárium v marketingu vysokej školy. Bratislava: R. S. Royal Service 2003, ISBN 80-968379-5-8

[2] KUPKOVIČ, M. a kol.: Podnikové hospodárstvo. Bratislava: ELITA 2002, ISBN 8088848-93-8

[3] Štatút Akadémie ozbrojených síl generála Milana Rastislava Štefánika so sídlom v Liptovskom Mikuláši, 2008, dostupné na http://web.aoslm.sk/

[4] KOZEL, R. a kol.: Moderní marketingový výzkum. Praha: Grada Publishing 2006, ISBN 80-247-0966-X

[5] PETERS, T.: Strategy Follows Structure, Developing Distinctive Skills. Callifornia Management Review, 1984, N. 11, p. 111-125, ISSN 0008-1256

[6] BUTORACOVÁ ŠINDLERYOVÁ, I.: Vybrané aspekty marketingu v rámci vzdelávacích organizácií. Marketing \& Komunikace. Vydané: 26. 10. 2007, ISSN 1211-5622, dostupné na http://www.mandk.cz

[7] ČÁBYOVÁ, L.: Marketing pomôže vyriešit' aj problémy vo vašej škole. Učitel'ské noviny. 2008, dostupné na www.unoviny.sk

[8] KELEMEN, M. - NEČAS, P.: Marketingový mix v podmienkach štátnej vysokej školy. Vystúpenie na medzinárodnej konferencii „Marketing vzdelávacích inštitúcií“ Žilina: MARVI, Žilinská univerzita FPEDAS, Katedra spojov, 6. - 7. november 2008

[9] KOTLER, P. - FOX, K. - CLIFFTS, E.: Strategic Marketing for Educational Institutions. Prentice Hall 1985

[10] SVĚTLÍK, J.: Marketing školy. Zlín: EKKA 1996, ISBN 80-902200-8-8

[11] ŠIGUT, Z.: Úloha marketingu ve vzdělávání dospělých: Marketing školy. Manažér, 13, 2008, č. 49, ISSN 1335-1729 